\title{
Ability of high hydrostatic pressure treated plasmids and cells of Escherichia coli to genetically transform ${ }^{\dagger}$
}

\author{
Arun Sharma, ${ }^{\star}$ Satyendra Gautam, Ram Krishna Fotedar, ${ }^{1}$ Paul Thomas, \\ Parthasaratmy Chenna Kesavan, and Rajagopala Chidambaram \\ Food Technology Division, Biosciences Group and \\ ${ }^{1}$ Metallurgy Division, Bhabha Atomic Research Centre, Mumbai-400085, India
}

(Received June 2, 1997; Accepted July 10, 1997)

\begin{abstract}
The exposure of plasmid pUC18 and pBR322 DNA to high hydrostatic pressure increased the ability of plasmids to transform competent Escherichia coli cells. For pUC18 plasmid, a pressure of $400 \mathrm{MPa}$, and for pBR322, a pressure of $200 \mathrm{MPa}$ was found to provide the highest transformation efficiency. The DNA duplexes of the two plasmids were found to be the most stable for melting conditions at these pressures. At pressures higher than these, both the stability of the duplex DNA and the transformation efficiency were affected. The stabilizing effect of high hydrostatic pressure on the hydrogen bond may be responsible for the observed increase in transformation efficiency of the pressure-exposed plasmid DNA. The possibility of pressure-induced changes in the structure and conformation of DNA was studied using various techniques. In agarose gel electrophoresis, pressure-treated plasmids (pUC18 at $400 \mathrm{MPa}$ and pBR322 at $200 \mathrm{MPa}$ ) consistently showed visibly distinct higher mobility compared to untreated plasmids. Pressure-treated pUC18 as well as pBR322 DNA showed significant reduction in ethidium bromide binding as is evident from the reduced intensity of fluorescence of the dye bound pressure-treated DNA. Spectroscopic studies using circular dichroism and Fourier transform infrared (FTIR) spectroscopy also showed significant differences in the absorption profiles of pressure-treated plasmids as compared to an untreated control. These studies revealed that the pressure-induced changes in the conformation of these DNAs may be responsible for the observed increase in the transformation ability of the plasmids. On the other hand, the exposure of competent cells of $E$. coli to a high hydrostatic pressure of $50 \mathrm{MPa}$ not only reduced their colony-forming ability but also drastically reduced their ability to take up plasmid DNA.
\end{abstract}

Key Words_conformational change; genetic transformation; high pressure; plasmid DNA

The use of high hydrostatic pressure in the range of $100-1,000 \mathrm{MPa}$ for the treatment of foods in order to extend their shelf-life and improve microbiological safety is being developed in many countries (Hoover et al., 1989; Mertens and Deplace, 1993; Tonello et al., 1994). The effects of high pressure on the viability of microorganisms and protein denaturation are well documented (Hoover et al., 1989; Smelt et al., 1994; Suzuki and Taniguchi, 1972). However, the mechanism of inactivation of the microbes and proteins by high pressure is still under investigation in a number

\footnotetext{
† Paper partly presented at the International Conference on Condensed Matter under High Pressure (ICCMHP-India, 1996) November 11-15, 1996, Mumbai, India.

* Address reprint requests to: Dr. Arun Sharma, Food Technology Division, Biosciences Group, Bhabha Atomic Research Centre, Mumbai-400085, India.
}

of laboratories (Chong et al., 1985; Smelt et al., 1994). To the best of our knowledge, the effect of high pressure on deoxyribonucleic acids (DNA) in relation to its uptake by the microbes (i.e., transformation ability) has not been studied. We investigated the effect of high-pressure treatment of DNA plasmids, pUC18 and pBR322, on their ability to transform competent Escherichia coli cells. We also investigated the ability of high pressure-treated E. coli cells to take up plasmid DNA and their transformation. The findings are reported in this paper.

\section{Materials and Methods}

Microorganism and plasmids. E. coli strain DH5 alpha (Hanahan, 1983) was used in this study. For transformation, competent cells of the bacterium were prepared using the standard calcium chloride method. 
Both pressure-treated and untreated competent cells were used in the study. The plasmids used were pUC18 (Ampr $, 2,690 \mathrm{bp})$ and pBR322 (amp ${ }^{r}$ and $t e t^{r}$, 4,363 bp).

Large-scale plasmid preparation. Large-scale plasmid preparations were made from cultures of $E$. coli strains carrying these plasmids (grown overnight). Pure plasmid preparations were made by ethidium bromide-cesium chloride density-gradient ultracentrifugation. Large-scale preparation of the plasmids, density-gradient centrifugation, and preparation of the competent cells were as per standard methods (Sambrook et al., 1989).

High-pressure treatment. High hydrostatic pressure treatment was carried out in a $800 \mathrm{kN}$ vertical hydraulic press designed and built by the Metallurgy Division of Bhabha Atomic Research Centre. The pressure intensifier consisted of multiple pressfit vessels designed to different hardness levels. The inner bore was $20 \mathrm{~mm}$ (diam.) $\times 100 \mathrm{~mm}$ long. A hardened plunger, fitted with a miter ring and Hallprene seal, moves in the bore, thereby generating isostatic pressure around the sample. The generated pressure was measured using a maganin coil by the Wheatstone bridge method. The equipment can provide pressures up to $1,000 \mathrm{MPa}$. For delivering high hydrostatic pressures, the sample of competent cells of the bacterium suspended in $50 \mathrm{~mm}$ calcium chloride and $15 \%$ glycerol or pure plasmid suspended in TE $(10 \mathrm{mM}$ Tris and $1 \mathrm{~mm}$ EDTA, $\mathrm{pH}$ 8.0), was placed in a latex rubber condom. The top was tied using a strong thread. The rubber condom was then placed in the bore of the vessel for delivering the desired pressure. After the treatment, the cells or the plasmids were recovered from the rubber condom and preserved in an Eppendorf tube.

Transformation of E. coli. Transformation of the competent cells of $E$. coli was carried out using a standard heat-shock procedure (Sambrook et al., 1989). After completion of the transformation procedure, an aliquot from the transformation mixture was plated on Luria-Bertani (LB) agar plates containing ampicillin (amp) $(50 \mu \mathrm{g} / \mathrm{ml})$ or tetracycline (tet) $(18 \mu \mathrm{g} / \mathrm{ml})$. The plates were incubated at $37^{\circ} \mathrm{C}$ and counted the next day for the transformants. Transformation efficiency was calculated as transformants/ $\mu \mathrm{g}$ of DNA and transformation frequency as transformants/total number of competent or survivors.

Means and standard deviations shown in the figures were calculated from at least 12-15 replicates from three different experiments.

Agarose gel electrophoresis. Agarose gel electrophoresis was carried out in $1 \%$ agarose gel at $4 \mathrm{~V} / \mathrm{cm}$ using Tris acetate EDTA (TAE) buffer (Sambrook et al., 1989). Agarose was procured from Sigma
Chemical Company, U.S.A. Equal volumes and concentrations of ultrapure untreated control and pressuretreated pUC18 (400 MPa) and pBR322 (200 MPa) plasmids along with lambda-Hindlll digested marker were subjected to electrophoresis. The gel was stained with ethidium bromide (Sambrook et al., 1989).

Ethidium bromide binding assay. For ethidium bromide binding assay, ethidium bromide $(0.5 \mu \mathrm{g} / \mathrm{ml})$ was added to $100 \mu \mathrm{l}$ of the plasmid DNA $(1.25 \mu \mathrm{g} / \mu \mathrm{l})$ and incubated for $30 \mathrm{~min}$ in the dark. Just before taking the spectrum, the volume was made to $3 \mathrm{ml}$ with Tris-EDTA buffer ( $10 \mathrm{~mm}$ Tris and $1 \mathrm{~mm}$ EDTA, pH 8.0). The fluorescence intensity was recorded in duplicate in a fluorescence spectrometer (LS 50B, Perkin Elmer, England). The excitation and emission wavelengths were 518 and $605 \mathrm{~nm}$, respectively. The slit width was $10 \mathrm{~nm}$.

Spectroscopic studies. Circular dichroism spectra of the pressure-treated pUC18 (400 MPa) and pBR322 (200 MPa) plasmids and untreated plasmids were obtained in a $\mathrm{J} 600$ spectropolarimeter (JSCO, Japan) at $26^{\circ} \mathrm{C}$. The DNA samples were diluted to a concentration of $12.5 \mu \mathrm{g} / \mathrm{ml}$ for obtaining the spectra. Duplicate scans were made for each sample.

Fourier transform infrared (FTIR) spectroscopy was carried out in a FTIR spectrometer (NICOLET, U. K.) using a sodium chloride window. Ten microliters of DNA sample $(12.5 \mathrm{mg} / \mathrm{ml})$ was used for recording the spectra. Duplicate scans were made for each sample.

\section{Results and Discussion}

The ability of high pressure-treated plasmid DNA to transform competent cells of $E$. coli DH5 alpha has been studied. For this purpose, pure DNA of the two plasmids pUC18 and pBR322 were exposed to high hydrostatic pressure in the range of $50-800 \mathrm{MPa}$, and used for transformation of the competent cells of the bacterium.

Figure 1 shows the transformation efficiency of pUC18 (amp) exposed to high pressure. With an exposure of pUC18 to a pressure of $400 \mathrm{MPa}$, the transformation frequency and transformation efficiency showed an enhancement of $355 \%$ over the unexposed plasmid DNA. However, pressure higher than $400 \mathrm{MPa}$ reduced the transformation ability of the plasmid, which dropped to almost control levels at $800 \mathrm{MPa}$. Figure 2(a) shows the transformation efficiency of pBR322 (amp) exposed to high pressure. With pBR322, the peak transformation ability was observed with exposure to a pressure of $200 \mathrm{MPa}$, an increase of more than $300 \%$ was observed over the transformation observed with the unexposed plasmid. However, unlike pUC18, exposure of plasmid pBR322 


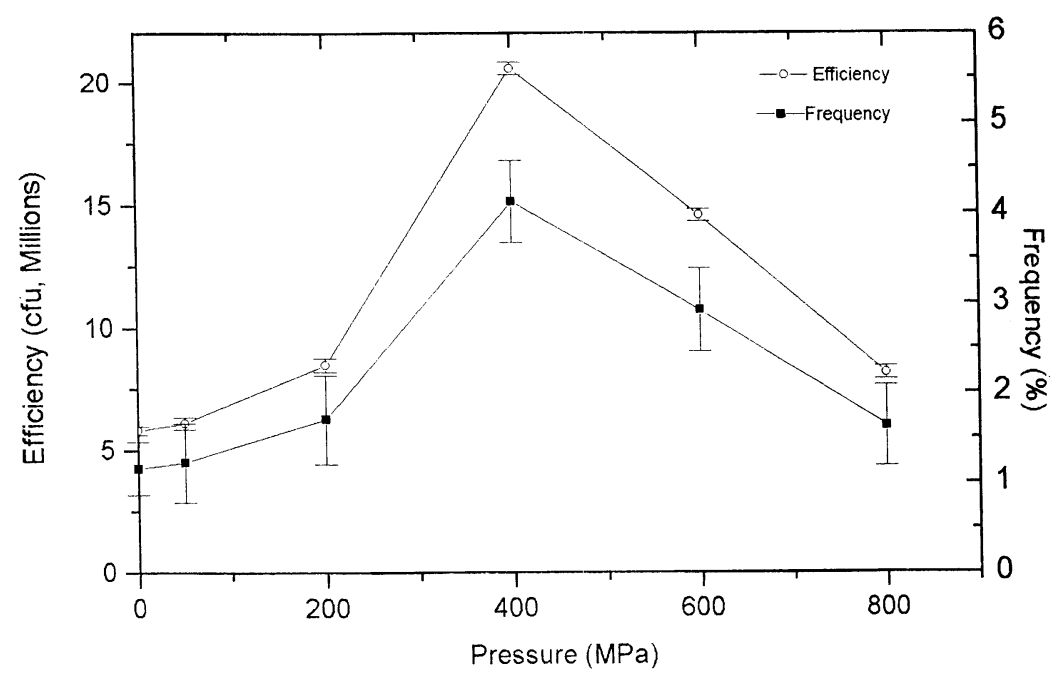

Fig. 1. Plasmid pUC18 DNA was exposed to high pressure (50-800 MPa).

The pressure-treated plasmid was used for transforming competent cells of $E$. coli. The number of transformants was determined by plating on LB agar containing ampicillin $(50 \mu \mathrm{g} / \mathrm{ml})$.

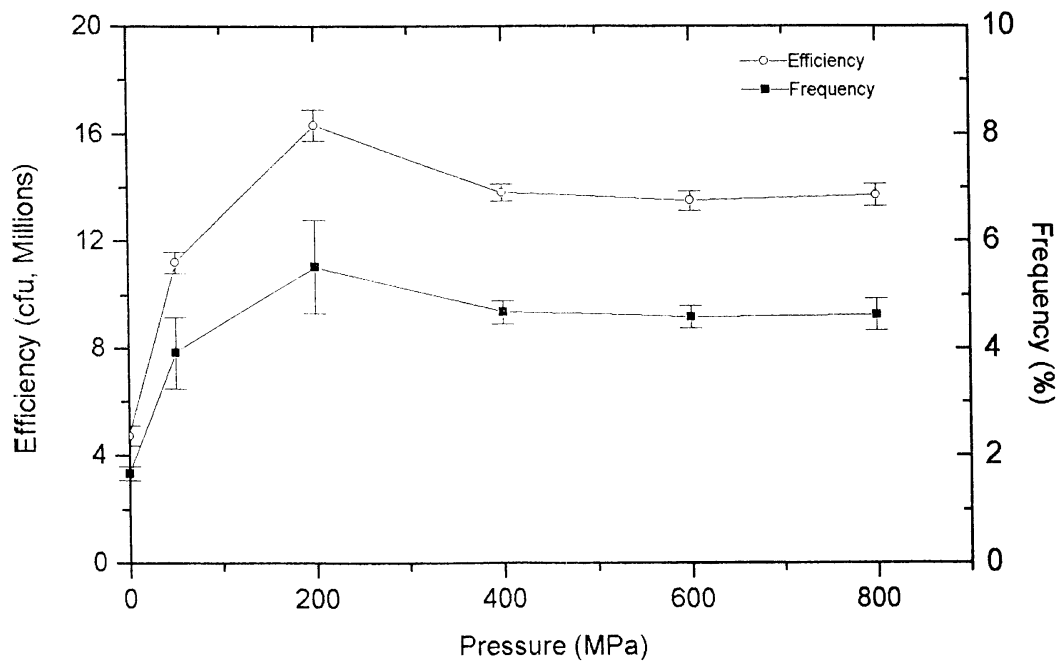

(a)

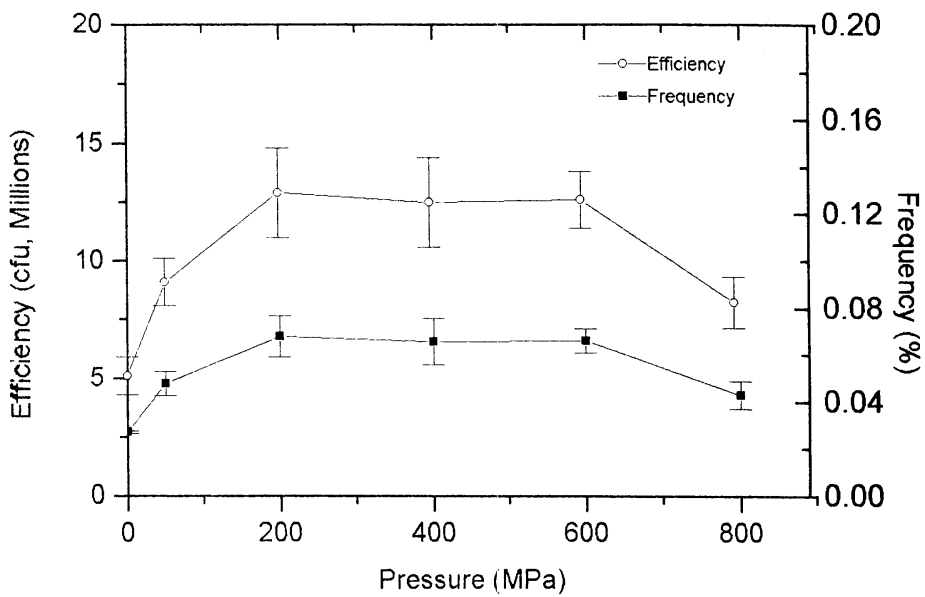

(b)

Fig. 2. (a) Pressure-exposed pBR322 DNA was used for transforming competent cells of $E$. coli.

The number of transformants was determined by plating on LB agar plates containing ampicillin $(50 \mu \mathrm{g} / \mathrm{ml})$.

(b) Pressure-exposed pBR322 DNA used for transforming competent cells of $E$. coli.

The number of transformants was determined by plating on LB agar plates containing tetracycline $(18 \mu \mathrm{g} / \mathrm{ml})$. 
to higher pressures between $400-800 \mathrm{MPa}$ did not cause any appreciable reduction in transformation ability in relation to the amp marker.

Similar results were also obtained with pBR322 (tet) and are shown in Fig. 2(b). Exposure of the plasmid to pressures up to $200 \mathrm{MPa}$ increased both the transformation efficiency and frequency by more than $250 \%$ over the unexposed plasmid. This increase in transformation ability remained stable up to $600 \mathrm{MPa}$ but fell drastically at a pressure of $800 \mathrm{MPa}$. In this plasmid, the observed increase in transformation ability with tet marker was smaller as compared to that with the amp marker.

The reasons for the differences in pressure requirements for pressure-induced enhancement in transformation ability, that is pUC18 requiring a pressure of $400 \mathrm{MPa}$ and pBR322 requiring $200 \mathrm{MPa}$, is not clear but could be attributed to differences in the plasmid size and their base compositions. The latter plasmid is about twice the size of the former and has a high GC content. High pressure is reported to stimulate reactions that result in volume decrease. Secondary bonds such as hydrogen bonds are favored and stabilized by high pressure since their formation involves a decrease in volume. DNA molecules are therefore stabilized rather than denatured by high pressure (Hoover et al., 1989). The two plasmids differ from each other in their GC content. The GC/AT ratio for the tet gene is 1.6 against 0.96 for the amp gene. The amp gene is common to both of the plasmids. pBR322 has an additional tet gene. Therefore, the total number of hydro- gen bonds in pBR322 is higher as compared to that in pUC18. As a result, the former is inherently more stable and probably requires lower pressure (200 MPa) as compared to the latter, which requires higher pressure $(400 \mathrm{MPa})$ for acquiring higher stability. It has been recently reported that buckling transitions in superhelical DNA depend on the size of DNA (Ramachandran and Schlick, 1997).

If high pressure has a stabilizing effect on the hydrogen bonds of DNA, then the duplex DNA molecules of pressure-exposed plasmids should be more resistant to conditions that allow melting (Suzuki and Taniguchi, 1972). To test this hypothesis, we studied the melting behaviors of the two DNA duplexes at various temperatures with conditions and agents that destabilize hydrogen bond such as $\mathrm{pH}$, temperature and formamide (Sambrook et al., 1989). Rather than using harsh destabilizing agents like formamide, milder conditions like low $\mathrm{pH}$ and high temperature were optimized and used to magnify and elucidate the small but significant differences in the stability of DNA duplexes as a result of exposure to high pressures. Figure 3 shows the absorbance patterns of the two plasmid duplex DNAs and a control as well as those exposed to high pressures, at $260 \mathrm{~nm}$. The plasmid pUC18 $(5 \mu \mathrm{l}, 0.5 \mu \mathrm{g} / \mu \mathrm{l})$ samples were suspended in $1.5 \mathrm{ml}$ sodium citrate buffer $(0.12 \mathrm{M}, \mathrm{pH} 4.0)$ and heated at $90^{\circ} \mathrm{C}$ for $30 \mathrm{~min}$. The plasmid pBR322 samples $(5 \mu \mathrm{l}, 0.3 \mu \mathrm{g} / \mu \mathrm{l})$ were suspended in $1.5 \mathrm{ml}$ sodium citrate buffer $(0.09 \mathrm{M}, \mathrm{pH} 3.0)$ and heated at $90^{\circ} \mathrm{C}$ for $90 \mathrm{~min}$. A clear hypochromic shift in absorbance at

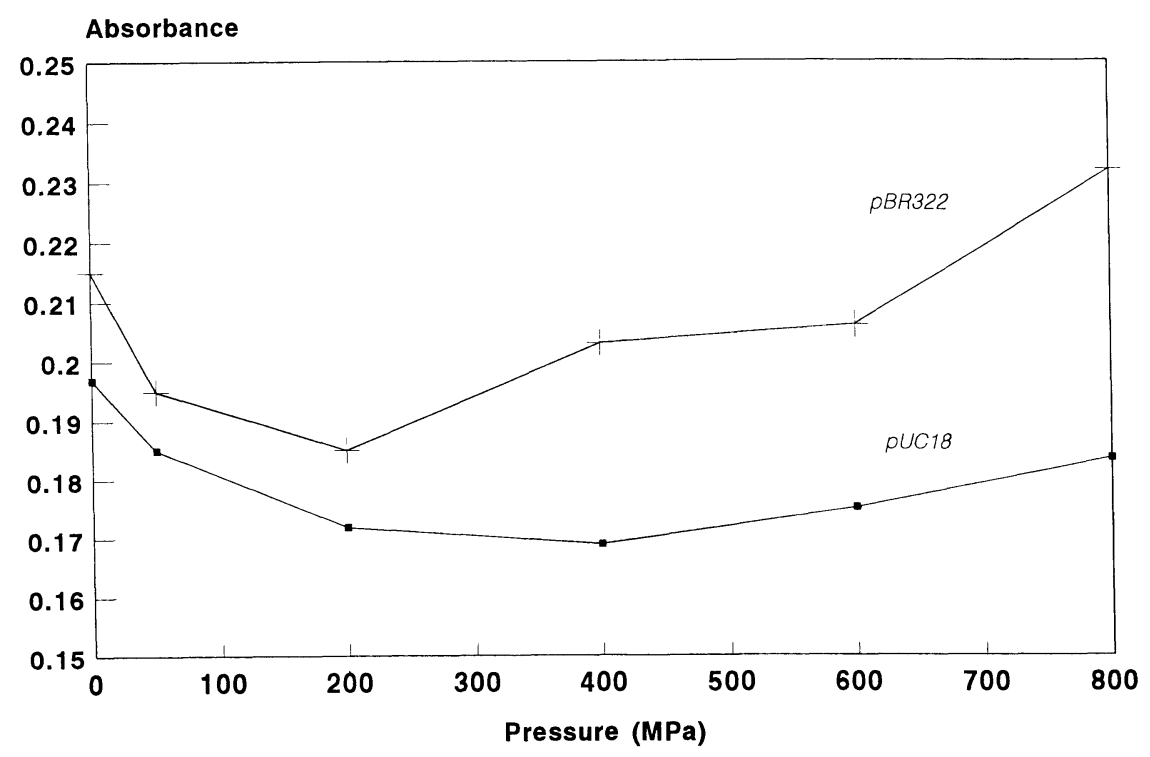

Fig. 3. Five microliters of duplex DNA of plasmids pUC18 $(0.5 \mu \mathrm{g} / \mu \mathrm{l})$ and pBR322 $(0.3 \mu \mathrm{g} / \mu \mathrm{l})$ exposed to various pressures $(50-800 \mathrm{MPa})$ were suspended in $1.5 \mathrm{ml}$ of sodium citrate buffer.

In order to study the melting behavior of pUC18, a buffer of conc. $0.12 \mathrm{M}$ and pH 4.0 and a heat treatment of $90^{\circ} \mathrm{C}$ for $30 \mathrm{~min}$ was employed; whereas, for that of pBR322, a buffer of $0.09 \mathrm{M}$ and $\mathrm{pH} 3.0$ and a heat treatment of $90^{\circ} \mathrm{C}$ for $90 \mathrm{~min}$ was employed. The absorbance of the melted DNA at $260 \mathrm{~nm}$ was recorded in a UV spectrophotometer. 
$260 \mathrm{~nm}$ could be observed in the two plasmid DNAs exposed to high pressure. The lowest absorbance or maximum hypochromicity at $260 \mathrm{~nm}$ was observed at a pressure of $400 \mathrm{MPa}$ in the case of pUC18; whereas, in the case of pBR322, it was observed at a pressure of $200 \mathrm{MPa}$. A further increase in pressure up to $800 \mathrm{MPa}$ resulted in hyperchromic shifts from this minima. In the case of pBR322, absorbance of plasmid DNA exposed to a pressure of $800 \mathrm{MPa}$ was found to be more than the control, the reason for which is not clear. It can therefore be inferred that the DNA of the two plasmids pUC18 and pBR322 acquired higher stability to conditions of melting after exposure to a pressure of 400 and $200 \mathrm{MPa}$, respectively, and exposure to these pressures also resulted in the plasmids acquiring higher transformation ability.

The possibility of a conformational change in plasmid DNA following exposure to high pressure has been assessed. For this, the plasmids were exposed to the pressure found to give the highest transformation ability (i.e., $400 \mathrm{MPa}$ for pUC18 and $200 \mathrm{MPa}$ for pBR322). The mobilities of the pressure-treated and control plasmids were compared by carrying out agarose gel electrophoresis. Figure 4 shows the agarose gel electrophoresis patterns of the pressuretreated and control plasmids of pUC18 and pBR322 DNA along with pressure-treated and control plasmids digested with EcoRI and HindIII restriction endonucleases. As seen from Fig. 4, an increase in the mobility

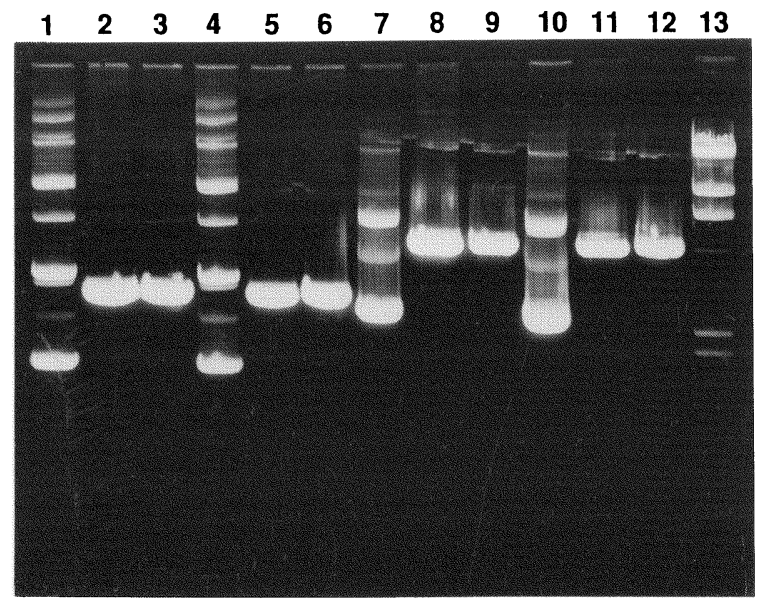

Fig. 4. Agarose gel electrophoresis profile of control and pressure-treated plasmids (pUC18 at $400 \mathrm{MPa}$ and pBR322 at $200 \mathrm{MPa}$ ) along with their $\mathrm{EcoRI}$ and HindlII restriction digested profile.

Lane 1, pUC18 (control); Lane 2, EcoRI digest of pUC18 (control); Lane 3, Hindlll digest of pUC18 (control); Lane 4, pUC18 (pressure treated); Lane 5, EcoRI digest of pUC18 (pressure treated); Lane 6, Hindlll digest of pUC18 (pressure treated); Lane 7, pBR322 (control); Lane 8, EcoRI digest of pBR322 (control); Lane 9, Hindlll digest of pBR322 (control); Lane 10, pBR322 (pressure treated); Lane 11, EcoRI digest of pBR322 (pressure treated); Lane 12, HindllI digest of pBR322 (pressure treated); Lane 13, lambda DNA HindllI digest (marker). of both the pressure-treated pUC18 (Lane 4) and pBR322 (Lane 10) plasmids and their concatemers in comparison to their controls (i.e., pUC18 (Lane 1) and pBR322 (Lane 7)) was evident. However, pressure treatment of the plasmids did not appear to affect the restriction of the plasmids by the two endonucleases.

An ethidium bromide binding study showed that the capacity to intercalate the dye was reduced in the pressure-treated pUC18 and pBR322 plasmids as is evident from the fluorescent intensity spectra of the two plasmids (Fig. 5a, b). It was reported that DNA

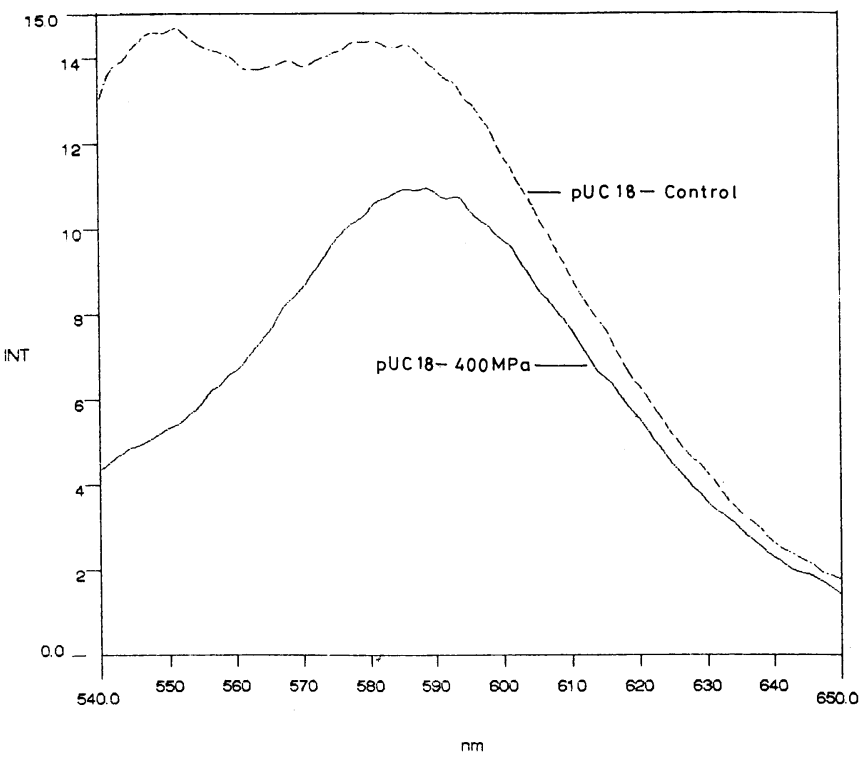

(a)

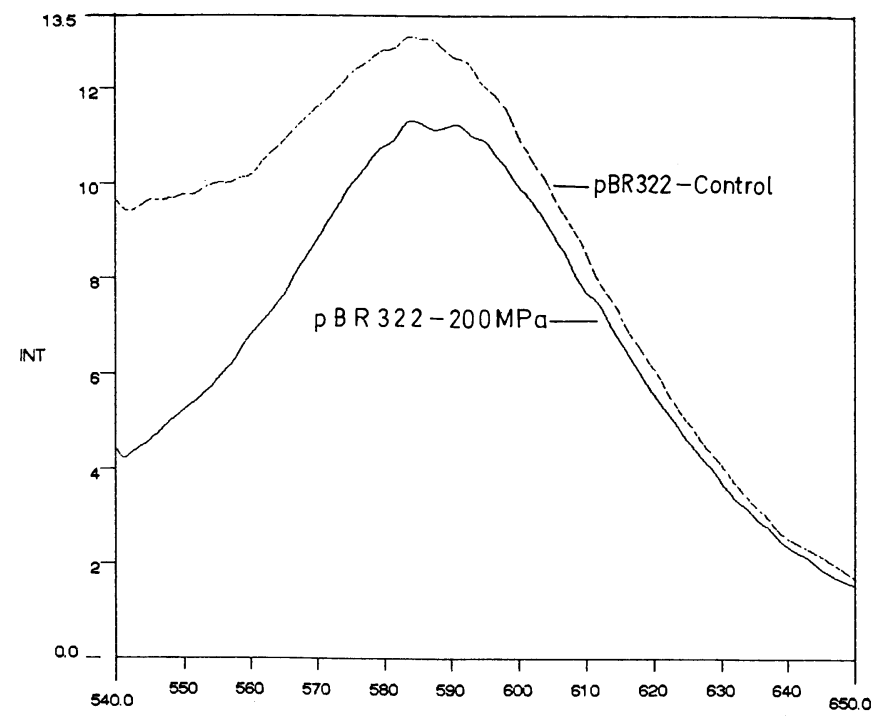

(b)

Fig. 5. (a) Fluorescence intensity spectra of ethidium bromide bound to control and $400 \mathrm{MPa}$ pressure-treated pUC18 DNA.

(b) Fluorescence intensity spectra of ethidium bromide bound to control and $200 \mathrm{MPa}$ pressure-treated pBR322 DNA. 
binding agents show highest affinity for the B-form of DNA compared to other conformations (Kopka et al., 1985). These results clearly show that a conformational change resulted in the lowering of the dye binding capacity, in the case of plasmids exposed to high pressure.

The results of the CD spectroscopic studies revealed that the plasmid pUC18 spectrum undergoes an increase in magnitude of the positive band in the $250-290 \mathrm{~nm}$ region following treatment with high pres- sure (Fig. 6a). In the case of pressure-treated pBR322, both increase $(275-280 \mathrm{~nm})$ and decrease $(255-260 \mathrm{~nm})$ in magnitude of the positive band were observed (Fig. 6b). The observed changes in magnitude of the $C D$ spectra of the two plasmids clearly show that the plasmids underwent conformational changes (Maestre and Wang, 1971). It is believed that a small alteration in the average rotation angle may cause significant differences in the number of superhelical turns in a molecule (Maestre and Wang, 1971),

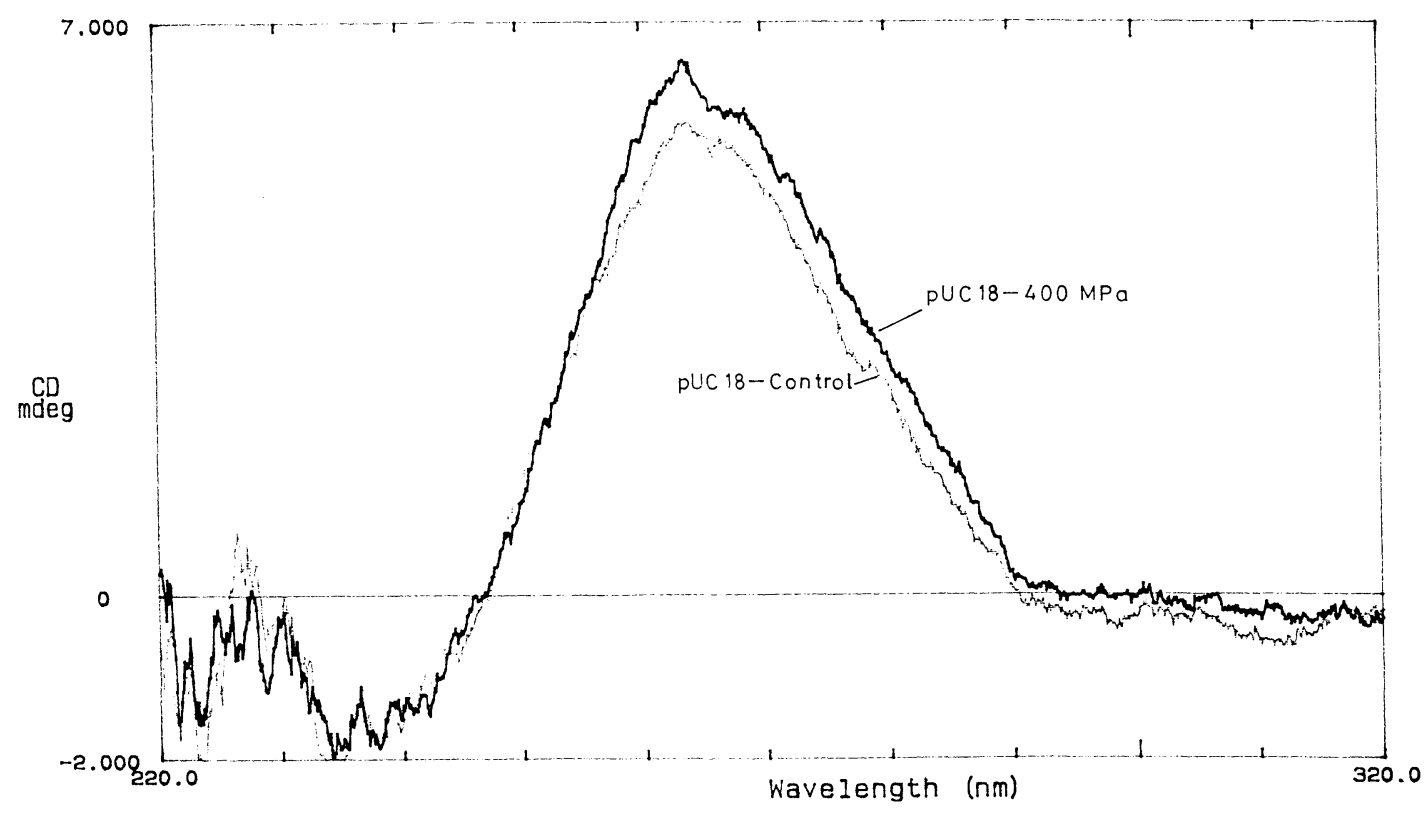

(a)

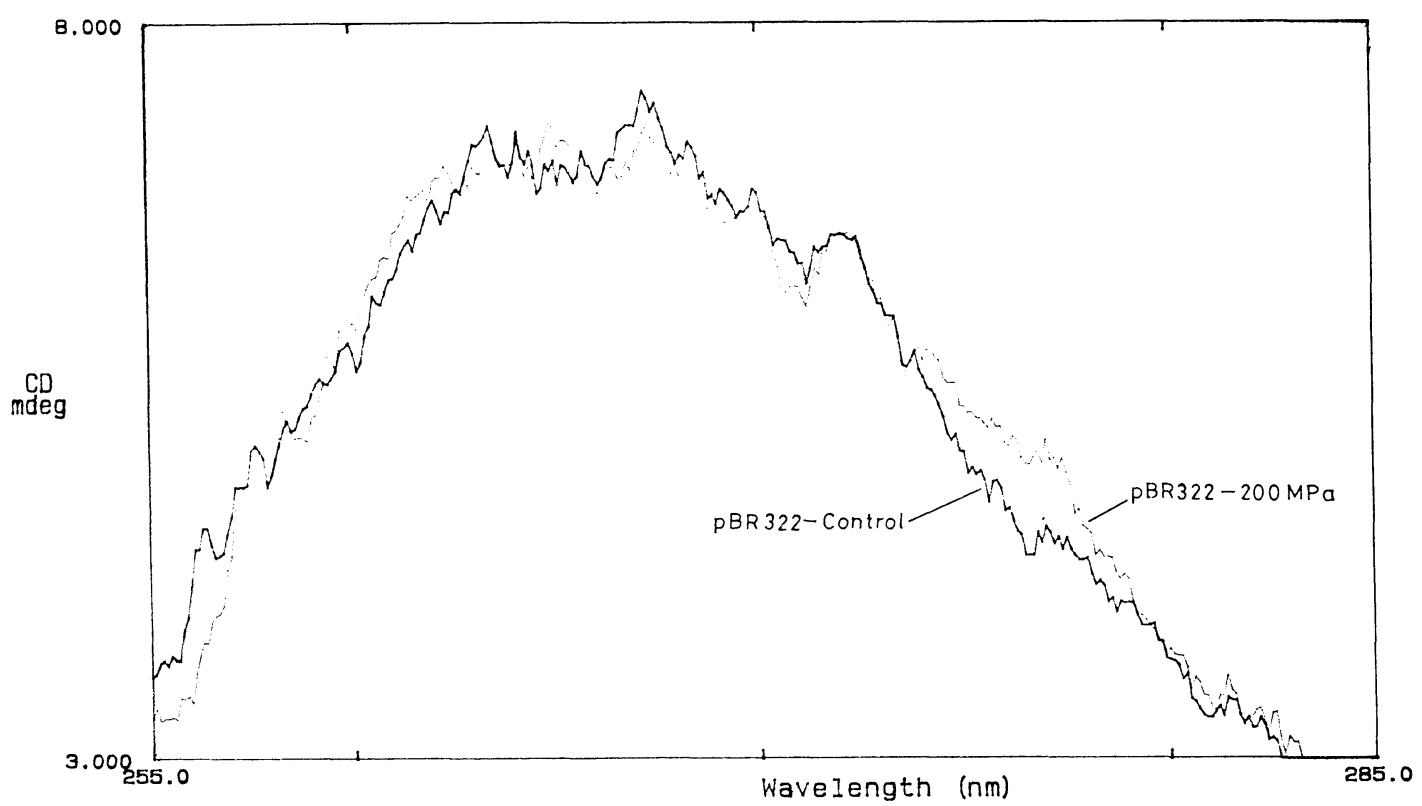

(b)

Fig. 6. (a) Circular dichroism spectra of control and $400 \mathrm{MPa}$ pressure-treated pUC18.

(b) Circular dichroism spectra of control and $200 \mathrm{MPa}$ pressure-treated pBR322. 
leading to conformational changes. It is probably these pressure-induced changes in the conformation of DNA that were responsible for the observed increase in efficiency of the transformation of pressuretreated plasmids. Using $C D$ spectroscopy, oligonucleotide duplexes have been shown to undergo $A-Z$ RNA conformational change following treatment with high pressure (Krzyzaniak et al., 1994a). High-pressure treatment of tRNA has also been reported to cause nonenzymatic specific amino-acylation (Krzyzaniak et al., 1994b).

Studies using FTIR spectroscopy (Fig. 7a, b, c, d) also revealed changes in the pressure-treated plasmids. These changes were evident from the increased

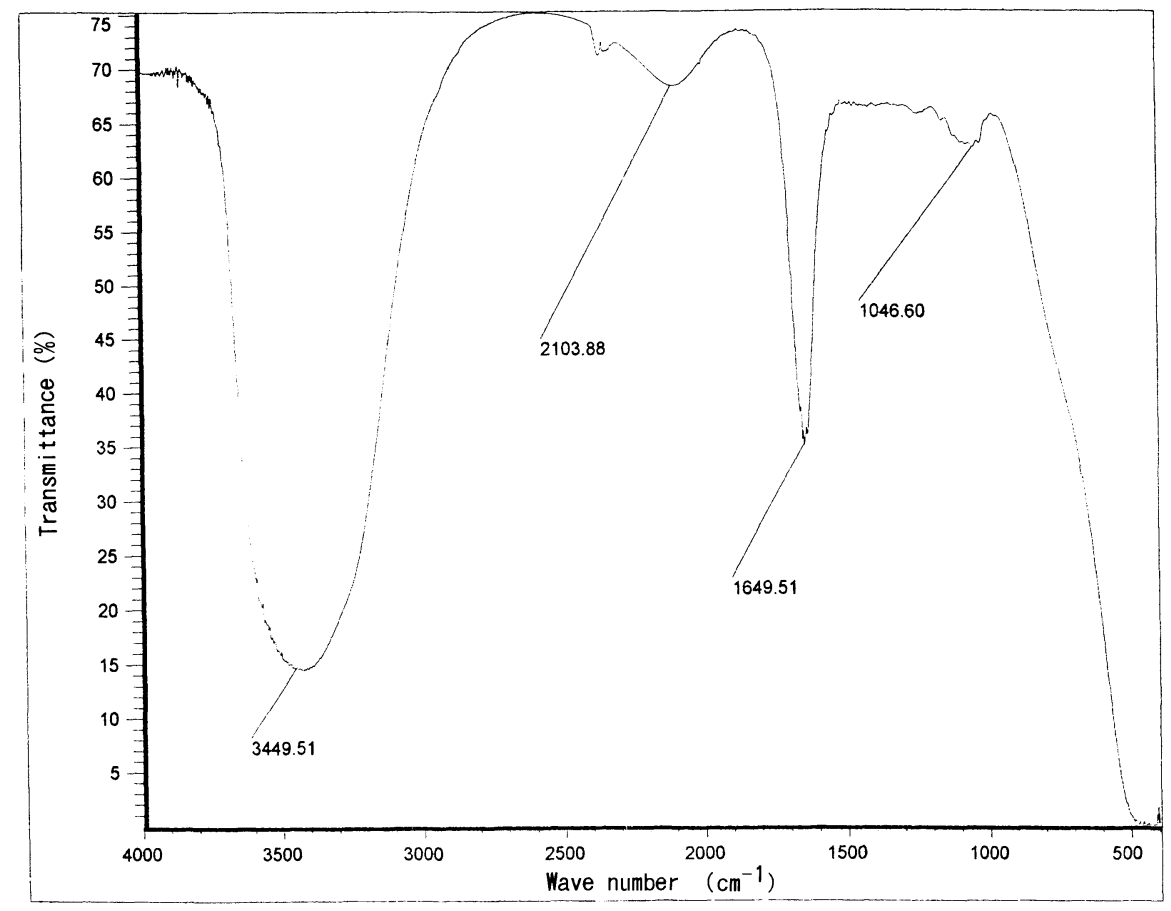

Fig. 7 (a). Fourier transform infrared (FTIR) spectrum of control pUC18.

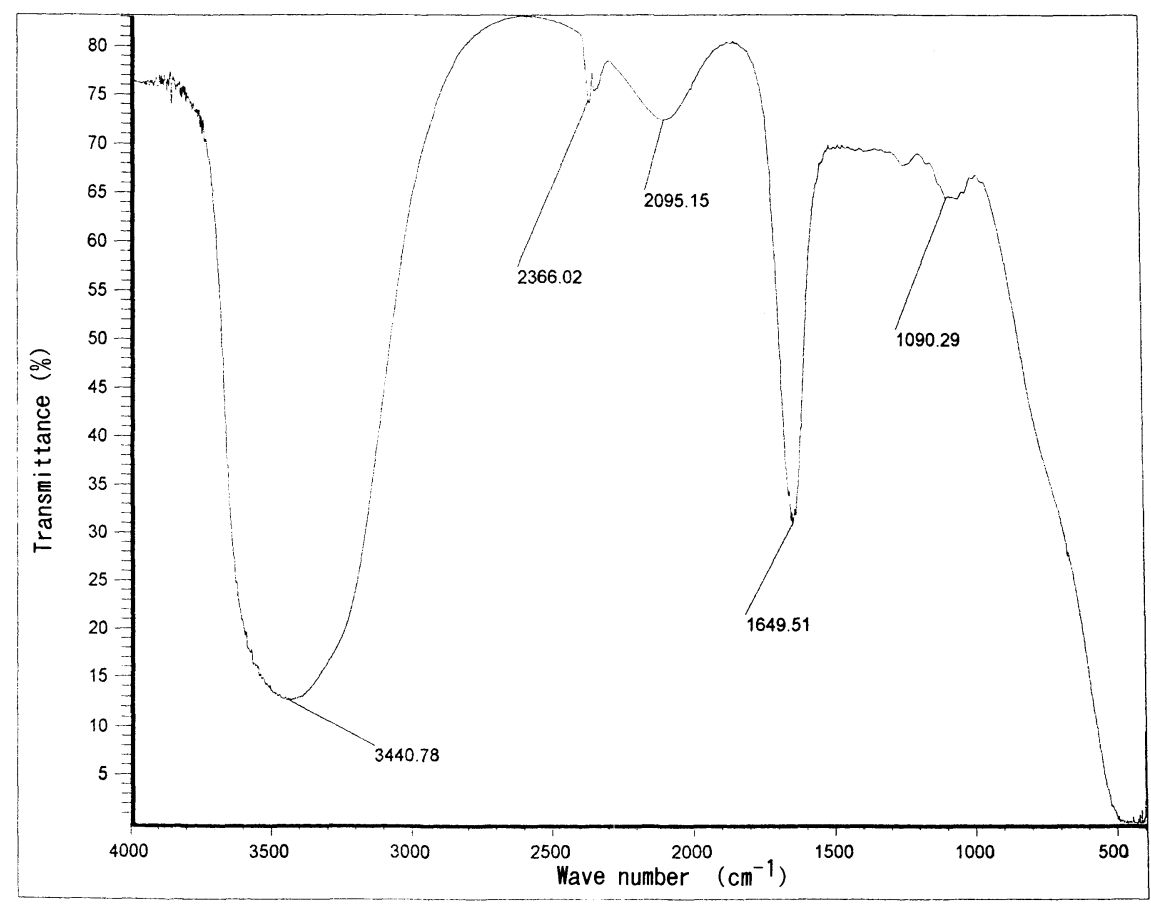

Fig. 7 (b). FTIR spectrum of $400 \mathrm{MPa}$ pressure-treated pUC18. 


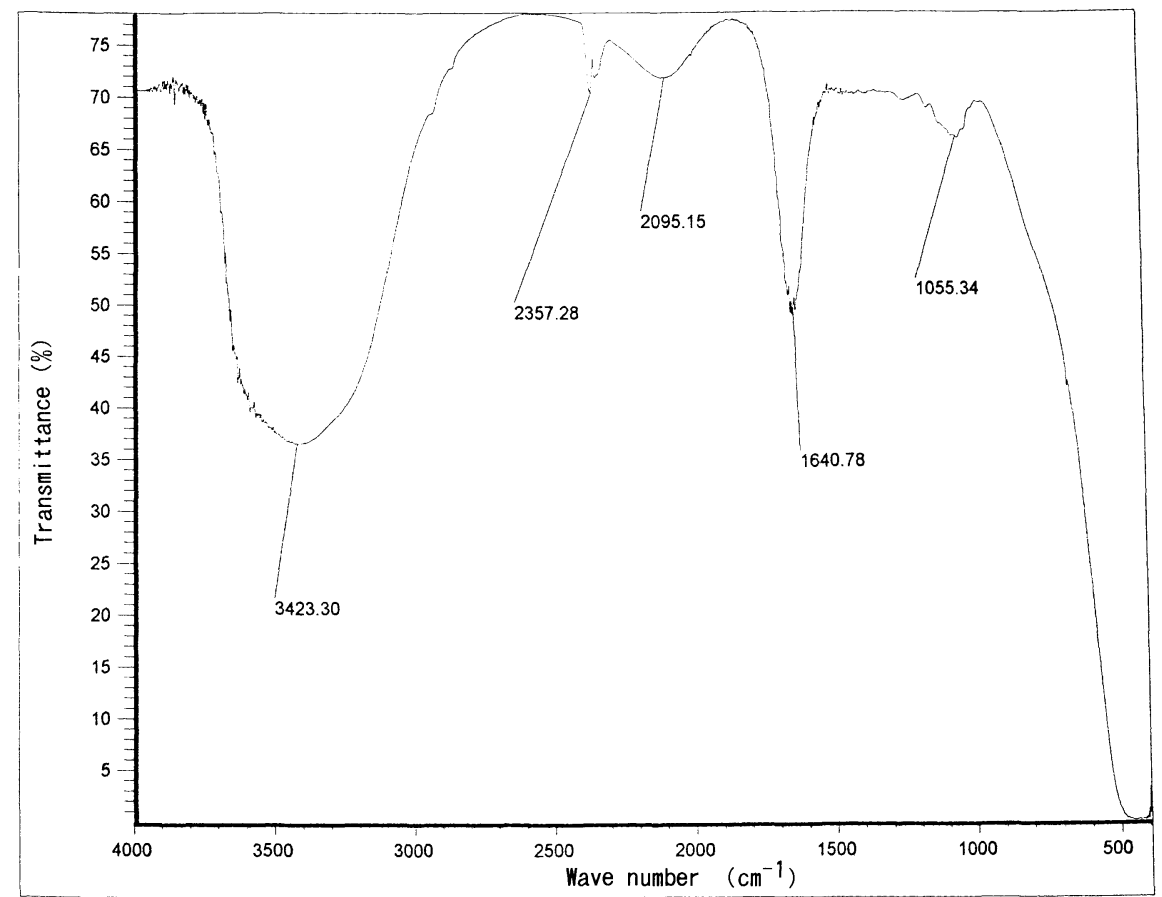

Fig. 7 (c). FTIR spectrum of control pBR322.

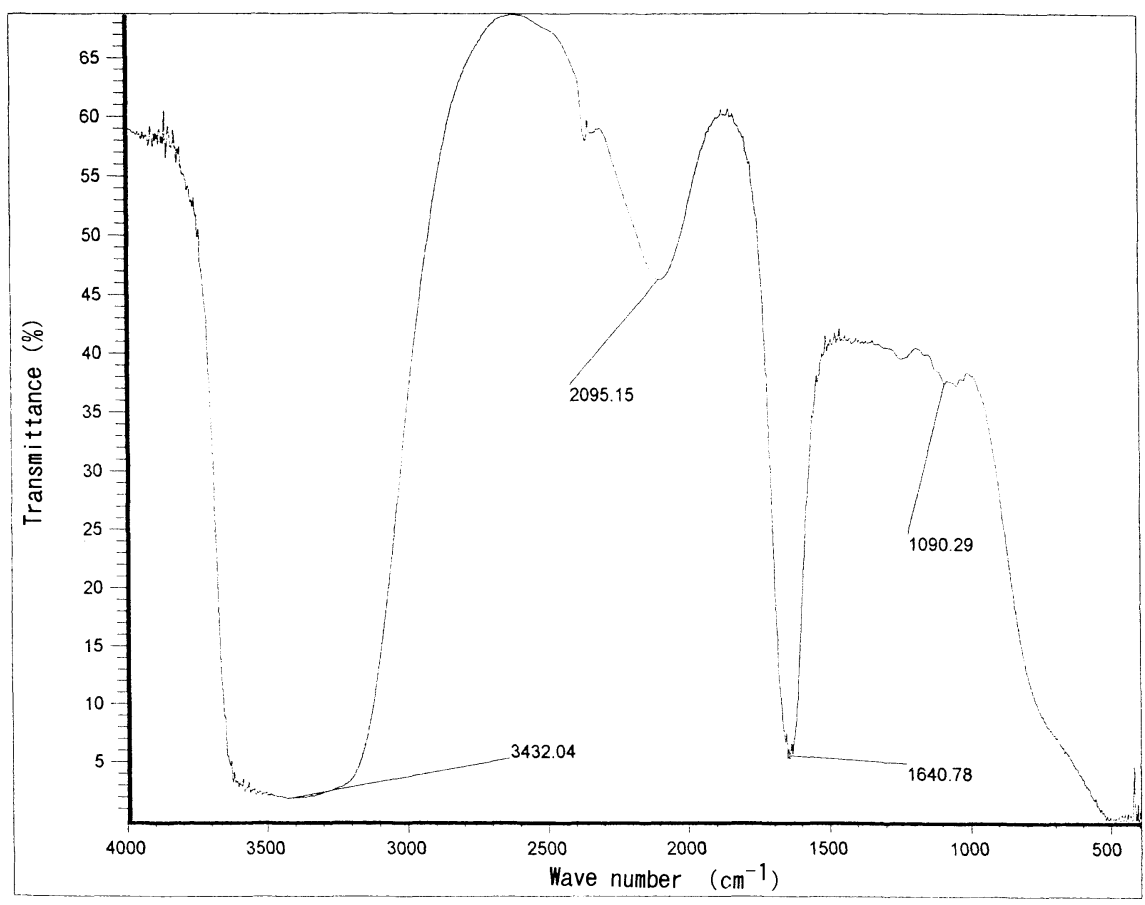

Fig. 7 (d). FTIR spectrum of $200 \mathrm{MPa}$ pressure-treated pBR322.

absorption or decreased transmittance in the 3,500$3,200 \mathrm{~cm}^{-1} \mathrm{NH}-\mathrm{OH}$ region (Tajmir-Riahi et al., 1994) and $2,095 \mathrm{~cm}^{-1}$ cumulative double-bond regions in the case of both pressure-treated pUC18 and pBR322 plasmids, indicating strengthening of hydrogen bonding between the bases. In the pressure-treated pUC18 plasmid, a shift in maximum absorption to the lower wave numbers $\left(3,449\right.$ to $3,440 \mathrm{~cm}^{-1}$ and 2,103 to $2,095 \mathrm{~cm}^{-1}$ ) was noticed. However, in the pBR322 plasmid, this shift was found to be on the higher side $\left(3,423\right.$ to $\left.3,432 \mathrm{~cm}^{-1}\right)$.

In the second set of experiments, the survival of the 


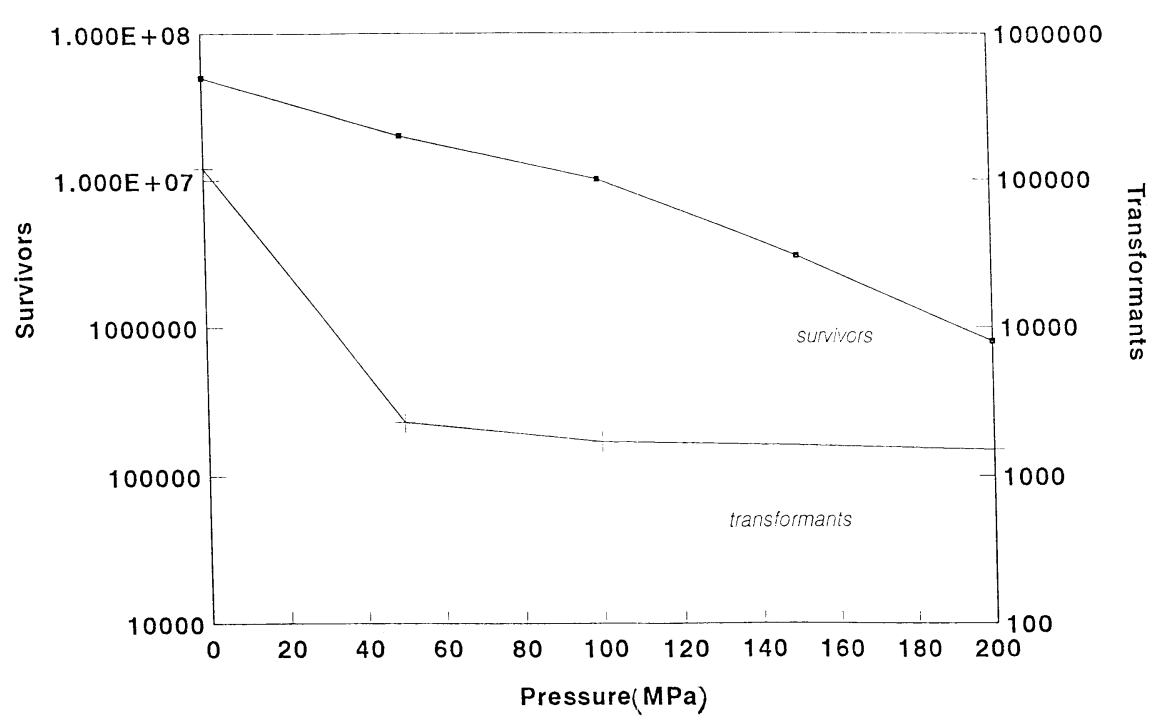

Fig. 8. Competent cells of $E$. coli were exposed to high pressure (50-200 MPa), and after exposure the number of survivors was determined by standard plate count on LB agar.

An aliquot of the pressure-treated cells was transformed with pUC18 plasmid, and the number of transformants was determined by plating on LB agar plates containing ampicillin $50 \mu \mathrm{g} / \mathrm{ml}$. The number of survivors and transformants has been plotted on log scale.

competent cells of $E$. coli $\mathrm{DH} 5$ alpha after exposure to high pressure and the transformation ability of the pressure-exposed cells with pUC18 DNA were investigated. Figure 8 shows the decrease in the survival of E. coli cells exposed to high pressure in the range of 50-250 MPa and decrease in transformation frequency of the high pressure-exposed cells by pUC18 plasmid. A $40 \%$ reduction in the survival of cells was observed with exposure to a pressure of $50 \mathrm{MPa}$. At $100 \mathrm{MPa}$, the surviving fraction reduced to $20 \%$ of the original population. The $D_{10}$ value for this organism was found to be $110 \mathrm{MPa}$. The transformation frequency of the cells, however, was found to be drastically affected after exposure to a pressure of $50 \mathrm{MPa}$. It fell to a mere $2 \%$ of the control frequency in the survivors. A further increase in pressure, however, resulted only in a marginal decrease. High hydrostatic pressure is considered to bring about the inactivation of microorganisms by causing changes in the fluidity of the cell membrane and inactivation of certain membrane proteins (Smelt et al., 1994). Reduction in the activity of $\mathrm{Na} / \mathrm{K}$ ATPase has been found to correlate well with the decrease in bilayer fluidity after exposure to high pressure (Chong et al., 1985). The observed decrease in transformation frequency appears to be the direct result of the action of high pressure on bacterial membrane. It can be inferred from these studies that membrane fluidity and $\mathrm{Na} / \mathrm{K}$ ATPase may have a role in the uptake of DNA by microorganisms and in their genetic transformation.

\section{Conclusions}

These results show that the exposure of competent E. coli cells to high hydrostatic pressures adversely affected the competence of the cells to take up DNA. On the other hand, the exposure of plasmid DNA to high pressures increased its transformation ability. The conformational changes and enhanced stability observed in the high pressure-exposed DNA may be responsible for the observed enhancement in the ability of pressure-treated plasmids to transform E. coli cells. The possibility of a conformational change in the plasmid DNA following treatment with pressure has been ascertained by agarose gel electrophoresis, ethidium bromide binding assay, circular dichroism and FTIR spectroscopic studies of the pressuretreated plasmids.

The stabilizing effect of high pressure against the heat denaturation of DNA has been earlier reported (Suzuki and Taniguchi, 1972). Even changes in the conformation of certain nucleic acids following exposure to high pressure have been studied (Krzyzaniak et al., 1994a, b). However, this is the first time an improvement in a functional property of DNA has been observed after exposure to high pressures. The observed improvement in the stability and function of DNA at high pressure may have implications for barophilic bacteria. A detailed spectroscopic study of pressure-induced transformation in plasmid DNA is in progress. 
The authors thank Dr. S. Chattopadhyay, Bio-organic Division, Dr. R. D'cunha, Spectroscopy Division and Mr. B. N. Pandey, Radiobiology and Biochemistry Division, Bhabha Atomic Research Centre for their help in carrying out FTIR and fluorospectrometric studies, and Dr. S. Majumdar, Tata Institute of Fundamental Research, Mumbai, for his help in carrying out CD spectroscopic studies.

\section{References}

Chong, P. L., Fortes, P. A. G., and Jameson, D. M. (1985) Mechanism of inhibition of $\mathrm{Na} / \mathrm{K}$ ATPase by hydrostatic pressure studied with fluorescent probes. J. Biol. Chem., 260, 14484-14490.

Hanahan, D. (1983) Studies on transformation of Escherichia coli with plasmids. J. Mol. Biol., 166, 557-580.

Hoover, D. G., Metrick, C., Papineau, A. M., Farkas, D. F., and Knorr, D. (1989) Biological effects of high pressure on food microorganisms. Food Technol., 43, 99-107.

Kopka, M. L., Yoon, C., Goodsell, D., Pjura, P., and Dickerson, R. E. (1985) The molecular origin of DNA-drug specificity in netropsin and distamycin. Proc. Natl. Acad. Sci. U.S.A., 82, 1376-1380.

Krzyzaniak, A., Barciszewski, J., Fuerste, J. P., Bald, R., Erdmann, V. A., Salanski, P., and Jurczak, J. (1994a) A-Z RNA conformational changes effected by high pressure. Int. J. Biol. Macromol., 16, 159-162.

Krzyzaniak, A., Barciszewski, J., Salanski, P., and Jurczak, J. (1994b) The non-enzymatic specific aminoacylation of transfer RNA at high pressure. Int. J. Biol. Macromol., 16, 153-158.
Maestre, M. F. and Wang, J. C. (1971) Circular dichroism of superhelical DNA. Biopolymers, 10, 1021-1031.

Mertens, B. and Deplace, D. (1993) Engineering aspects of high pressure technology in food industry. Food Technol., 47, 164168.

Ramachandran, G. and Schlick, T. (1997) Buckling transitions in superhelical DNA: Dependence on the elastic constants and DNA size. Biopolymers, 41, 5-25.

Sambrook, J., Fritsch, E. F., and Maniatis, T. (1989) Molecular Cloning: A Laboratory Manual, Cold Spring Harbour Laboratory, Cold Spring Harbour, New York, pp. 1.33-6.34.

Smelt, J. P. P. M., Rijke, A. G. F., and Hayhurst, A. (1994) Possible mechanism of high pressure inactivation of microorganisms. High Pressure Res., 12, 199-203.

Suzuki, K. and Taniguchi, Y. (1972) Effect of pressures on biopolymers and model systems. In The Effects of Pressure on Living Organisms, ed. by Sleigh, M. A. and MacDonald, A. G., Academic Press, New York, p. 103.

Tajmir-Riahi, H. A., Naoui, M., and Diamantoglou, S. (1994) DNAcarbohydrate interaction. The effects of mono- and disaccharides on the solution structure of calf-thymus DNA. J. Biomol. Struct. Dyn., 12, 217-234.

Tonello, C., Wurtz, P., Largeteau, A., Jolibert, F., Deschamps, A., Ducastaing, A., and Demazeau, G. (1994) Recent developments in the use of high hydrostatic pressures in food processing. High Pressure Res., 12, 205-213. 